\title{
FIRE HISTORY, STAND ORIGINS, AND THE PERSISTENCE OF MCNAB CYPRESS, NORTHERN CALIFORNIA, USA
}

\author{
Chris R. Mallek \\ Graduate Group in Ecology and Department of Plant Sciences, \\ University of California, Davis, California 95616, USA \\ Tel.: 001-530-752-2644; e-mail: crmallek@ucdavis.edu
}

\begin{abstract}
Despite their substantial contribution to the uniqueness and diversity of the California Floristic Province's flora and vegetation, surprisingly little is known about the region's native cypress species (genus Hesperocyparis Bartel \& R.A. Price). Current ideas about the fire regimes that maintained these species in the past are based largely or solely on assumptions about the expression and function of life-history characteristics. Empirical studies of fire history are generally lacking. I used a combination of dendrochronological methods, field observations, and contemporary fire records to investigate the history of fire and its role in stand development in McNab cypress (Hesperocyparis macnabiana [A. Murray bis] Bartel), an uncommon serotinous cypress endemic to northern California. Although even-aged stands were present within all 20 populations surveyed, 4 populations also contained stands exhibiting uneven age structure. Fire records and field observations confirmed that even-aged stands originated following stand-replacing fires, but no link between fire and recruitment was found for uneven-aged stands. Rather, trees within uneven-aged stands were generally older, larger, and exhibited higher rates of senescence than those found in even-aged stands, suggesting that inter-fire tree mortality and inter-fire establishment may be linked. When aggregated, the dates of stand-replacing fires (derived from stand recruitment dates and fire records) revealed that relatively few stand-replacing fires occurred in $\mathrm{McNab}$ cypress populations during the $50 \mathrm{yr}$ period between 1940 and 1989 ( 1 fire per decade) compared to either the previous $100 \mathrm{yr}$ period (at least 3 fires per decade) or the subsequent $20 \mathrm{yr}$ period ( 3.5 fires per decade). This suggests that short fire return intervals do not appear to be a significant threat to $\mathrm{McNab}$ cypress persistence at the present time, and there is little ecological justification for fire exclusion.
\end{abstract}

Keywords: age structure, California Floristic Province, fire history, fire regime, Hesperocyparis macnabiana, McNab cypress, northern California, serotiny, serpentine

Citation: Mallek, C.R. 2009. Fire history, stand origins, and the persistence of McNab cypress, northern California, USA. Fire Ecology 5(3): 100-119. doi: 10.4996/fireecology.0503100 


\section{INTRODUCTION}

Recurrent fire imposes strong selection on plants such that the evolution of plant traits and the distribution of plant species are profoundly shaped by variation in fire regimes (e.g., Clark 1996, Schwilk and Ackerly 2001). Thus, a change in fire regime, depending on its magnitude and rapidity, can have severe consequences for species persistence. This has major implications for fire management in the California Floristic Province (CFP), a region known for its exceptional levels of plant species diversity and endemism (Myers et al. 2000), where recurrent fire has featured prominently for millennia (Swetnam 1993, Mohr et al. 2000, Wathen 2006, Beaty and Taylor 2009). In many ecosystems throughout the CFP, factors such as fire exclusion, climate change, land-use change, and invasive species have driven fire regimes outside of their historic ranges of variability (Sugihara et al. 2006, Westerling et al. 2006, Miller et al. 2009), and pressure from these factors is likely to continue. This elevates the importance of fire history studies because they aid in the development of ecologically appropriate fire management goals by providing information about: (1) fire regimes that supported species in the past, and (2) if and how those regimes have changed (Swetnam et al. 1999, Millar et al. 2007). The need for this information is particularly acute for species that are both globally rare and locally dominant because when these species are affected, the consequences for ecosystem composition, structure, and function, as well as regional and global biodiversity, can be especially severe (Ellison et al. 2005). The cypress species (Hesperocyparis Bartel \& R.A. Price) of the CFP fit these criteria well.

The scarcity of fire history studies pertaining to cypress species in the CFP is surprising given their considerable contribution to the uniqueness and diversity of the region's flora and vegetation. Although a lack of consensus regarding cypress taxonomy has traditionally precluded definitive statements about the geographic distribution of intrageneric diversity, most of the recent treatments of the group recognized 16 distinct species, including 13 native to the CFP, 12 of which are endemic (Minnich 1987, Hickman 1993, Little 2006, Adams et al. 2009). Cypress species in the CFP exhibit highly fragmented distributions, which partly reflect their tendency toward poor soils or otherwise marginal habitats. However, at the local scale, they typically dominate the vegetation to form distinct communities that are both unique to and rare within the region (Minnich 1987, Sawyer et al. 2009). As the defining species for over $2 \%$ of the recognized vegetation types in alta California alone (Sawyer et al. 2009), yet comprising only about $0.19 \%$ of the vascular flora (Hickman 1993, Adams et al. 2009), cypress species contribute disproportionately to the state's high vegetation diversity.

The paucity of fire history information is most conspicuous for McNab cypress (Hesperocyparis macnabiana [A. Murray bis] Bartel) because (1) it is arguably the most widespread and abundant cypress species in the CFP (yet still uncommon) (Griffin and Critchfield 1972, Vogl et al. 1977), and (2) there is a critical need for responsible management of remaining populations in the face of increasing anthropogenic threats (C.R. Mallek, University of California, Davis, personal observation). McNab cypress occurs in portions of the North Coast Range, southern Cascade Range, and northern Sierra Nevada surrounding northern California's Sacramento Valley, typically on ultramafic substrates between $300 \mathrm{~m}$ and 1100 $\mathrm{m}$ elevation. This relatively low elevation range places approximately half of the species' distribution on private land where it is increasingly impacted by development and other human activities. One of the largest populations was destroyed in the early 1960s with the cre- 
ation of Whiskeytown Lake and National Recreation Area (Griffin and Critchfield 1972), but, in recent years, public land management agencies have started to express interest in maintaining $\mathrm{McNab}$ cypress populations and the plant communities that they dominate (Keeler-Wolf 2004; J. Gibson, National Park Service, personal communication; L. Hanson, Forest Service, personal communication; J. Weigand, Bureau of Land Management, personal communication).

Current understanding of historic fire regimes in $\mathrm{McNab}$ cypress populations are based largely on assumptions about the species' lifehistory traits. Like all cypress species within the CFP (except San Pedro Matir cypress $(H$. montana [Wiggins] Bartel), McNab cypress retains seeds within persistent closed cones for a year or more following seed maturation, a trait typically referred to as serotiny. McMaster and Zedler (1981) proposed that serotiny is most strongly favored under a regime of large, spatially uniform, stand-replacing (i.e., very high severity, sensu Romme [1980]) crown fires occurring at intervals longer than the mean juvenile period and shorter than the mean potential life-span of the species. For serotinous species incapable resprouting, these fires are expected to cause complete mortality in the parent generation, induce seed release from storage structures, and produce evenaged stands characterized by unimodal age distributions (Lamont et al. 1991, Veblen 1992).

Although the presence of a serotinous species within a plant community is often thought to imply a history of stand-replacing fires, empirical studies increasingly indicate that this assumption is not always accurate. For example, in communities dominated by two serotinous pines in eastern North America, Table Mountain pine (Pinus pungens Lamb.) and pitch pine ( $P$. rigida Mill.), tree growth patterns, fire scars, and stand age structure revealed that pine regeneration had occurred fol- lowing fires of varying severities and, in some cases, in the absence of fire altogether (Brose and Waldrop 2006). Moreover, the degree to which serotiny is expressed can vary among serotinous species (McMaster and Zedler 1981, Bond 1985, Cowling and Lamont 1985), can vary spatially and temporally within species (Givnish 1981, Borchert 1985, Cowling and Lamont 1985, Gauthier et al. 1996, Schoennagel et al. 2003), and can vary with factors not associated with fire (e.g., predispersal seed predation; Benkman and Siepielski [2004]). Serotinous taxa also differ with respect to the type of proximal cue required to initiate seed release (Zedler 1986). In light of these complications, conclusions about historic fire regimes and the development of fire management strategies should, to the greatest extent possible, integrate inferences derived from multiple lines of evidence rather than rely on assumptions based on life-history characteristics alone. Importantly, with the notable exception of giant Sequoia (Sequoiadendron giganteum [Lind.] J. Buchholz) (Swetnam 1993), assumptions about historic fire regimes have not been rigorously tested for any of the world's $\approx 30$ serotinous species in the Cupressaceae (Lamont et al. 1991; D.P. Little, New York Botanical Garden, unpublished data).

The goal of this study was to improve understanding of stand origins and fire history in $\mathrm{McNab}$ cypress populations throughout the species' range. Specifically, I combined treering data with modern fire records and field observations to address the following questions: (1) are $\mathrm{McNab}$ cypress stands even-aged or uneven-aged?; (2) are even-aged stands the result of stand-replacing fires?; (3) is fire necessary for McNab cypress recruitment?; and (4) are $\mathrm{McNab}$ cypress populations currently threatened by excessively short or long fire return intervals? Answers to these questions will provide an important empirical basis upon which sustainable fire management strategies for $\mathrm{McNab}$ cypress can be refined. 


\section{METHODS}

Field data were obtained from 20 populations selected at random from a pool of $\mathrm{McNab}$ cypress populations initially identified from the scientific literature, unpublished government documents, herbarium collections, and local experts (Table 1). A number of reported populations were excluded from consideration because they were too small, too heavily impacted by development, could not be located, no longer exist, or because access was either too difficult or prohibited by the landowner.
Nevertheless, the populations used in this study captured a representative spectrum of the species' geographic, climatic, and edaphic habitat diversity, and constitute approximately half of the populations known to exist at the time of writing.

Within each population, sampling was restricted to areas in which McNab cypress dominated the vegetation with $>50 \%$ basal area. However, community composition and structure varied considerably within this set. In the North Coast Range, communities typically consisted of a continuous $3 \mathrm{~m}$ to $5 \mathrm{~m} \mathrm{McNab}$

Table 1. Location, elevation, extent class $(<1,1$ to 10,10 to 100,100 to $1000,>1000$ ha), and ownership information for McNab cypress populations surveyed between 2006 and 2009 in the North Coast Range, northern Sierra Nevada, and southern Cascade Range of northern California.

\begin{tabular}{|c|c|c|c|c|c|}
\hline Population & County & Latitude, longitude & $\begin{array}{c}\text { Elev. } \\
\text { (m) }\end{array}$ & $\begin{array}{c}\text { Extent class } \\
\text { (ha) }\end{array}$ & Ownership $^{1}$ \\
\hline \multicolumn{6}{|l|}{ North Coast Range } \\
\hline Frenzel Creek & Lake & $39^{\circ} 17^{\prime} 2^{\prime \prime} \mathrm{N}, 122^{\circ} 32^{\prime} 48^{\prime \prime} \mathrm{W}$ & 654 & 10 to 100 & FS \\
\hline High Valley & Lake & $39^{\circ} 3{ }^{\prime} 54^{\prime \prime} \mathrm{N}, 122^{\circ} 43^{\prime} 6^{\prime \prime} \mathrm{W}$ & 793 & $<1$ & private \\
\hline Highland Springs & Lake & $38^{\circ} 56^{\prime} 36^{\prime \prime} \mathrm{N}, 122^{\circ} 57^{\prime} 29^{\prime \prime} \mathrm{W}$ & 602 & 10 to 100 & private \\
\hline Hooker Canyon & Sonoma & $38^{\circ} 22^{\prime} 12^{\prime \prime} \mathrm{N}, 122^{\circ} 27^{\prime} 47^{\prime \prime} \mathrm{W}$ & 590 & 1 to 10 & private \\
\hline Indian Valley & Lake & $39^{\circ} 9^{\prime} 58^{\prime \prime} \mathrm{N}, 122^{\circ} 31^{\prime} 31^{\prime \prime} \mathrm{W}$ & 488 & 10 to 100 & BLM \\
\hline Knoxville & Napa & $38^{\circ} 49^{\prime} 37^{\prime \prime} \mathrm{N}, 122^{\circ} 23^{\prime} 3^{\prime \prime} \mathrm{W}$ & 593 & 100 to 1000 & BLM, UC \\
\hline Pacific Ridge & Colusa, Lake & $39^{\circ} 12^{\prime} 53^{\prime \prime} \mathrm{N}, 122^{\circ} 35^{\prime} 23^{\prime \prime} \mathrm{W}$ & 1101 & 10 to 100 & FS \\
\hline Palisades & Napa & $38^{\circ} 38^{\prime} 31^{\prime \prime} \mathrm{N}, 122^{\circ} 33^{\prime} 55^{\prime \prime} \mathrm{W}$ & 689 & 1 to 10 & private \\
\hline Raglin Ridge & Tehama & $40^{\circ} 0 ’ 29 ” \mathrm{~N}, 122^{\circ} 39^{\prime} 39^{\prime \prime} \mathrm{W}$ & 927 & 10 to 100 & FS, private \\
\hline Walker Ridge & Colusa, Lake & $39^{\circ} 6 ’ 58^{\prime \prime} \mathrm{N}, 122^{\circ} 29^{\prime} 10^{\prime \prime} \mathrm{W}$ & 802 & 100 to 1000 & BLM, private \\
\hline \multicolumn{6}{|c|}{ Sierra Nevada and Cascade Range } \\
\hline Ash Creek & Shasta & $40^{\circ} 28^{\prime} 8^{\prime \prime} \mathrm{N}, 121^{\circ} 55^{\prime} 36^{\prime \prime} \mathrm{W}$ & 876 & 1 to 10 & private \\
\hline Bald Mountain & Yuba & $39^{\circ} 20^{\prime} 2^{\prime \prime} \mathrm{N}, 121^{\circ} 0 ’ 44^{\prime \prime} \mathrm{W}$ & 935 & 1 to 10 & BLM \\
\hline Concow & Butte & $39^{\circ} 48^{\prime} 52^{\prime \prime} \mathrm{N}, 121^{\circ} 31^{\prime} 1^{\prime \prime} \mathrm{W}$ & 841 & 10 to 100 & FS, private \\
\hline Daken Flat & Yuba & $39^{\circ} 27^{\prime} 34^{\prime \prime} \mathrm{N}, 121^{\circ} 17^{\prime} 17^{\prime \prime} \mathrm{W}$ & 675 & $<1$ & local gov. \\
\hline Deadman's Flat & Nevada & $39^{\circ} 12^{\prime} 37^{\prime \prime} \mathrm{N}, 121^{\circ} 6^{\prime} 48^{\prime \prime} \mathrm{W}$ & 706 & 1 to 10 & private \\
\hline Indiana Creek & Yuba & $39^{\circ} 25^{\prime} 18^{\prime \prime} \mathrm{N}, 121^{\circ} 14^{\prime} 42^{\prime \prime} \mathrm{W}$ & 617 & 10 to 100 & private \\
\hline Lake Mildred & Yuba & $39^{\circ} 22^{\prime} 22^{\prime \prime} \mathrm{N}, 121^{\circ} 16^{\prime} 4^{\prime \prime} \mathrm{W}$ & 521 & 10 to 100 & private \\
\hline Magalia & Butte & $39^{\circ} 50^{\prime} 5^{\prime \prime} \mathrm{N}, 121^{\circ} 35^{\prime} 8^{\prime \prime} \mathrm{W}$ & 756 & 10 to 100 & FS, local gov. \\
\hline Montgomery Crk. & Shasta & $40^{\circ} 50^{\prime} 39^{\prime \prime} \mathrm{N}, 121^{\circ} 56^{\prime} 17^{\prime \prime} \mathrm{W}$ & 614 & 1 to 10 & private \\
\hline River Pines & Amador & $38^{\circ} 32^{\prime} 24^{\prime \prime} \mathrm{N}, 120^{\circ} 44^{\prime} 11^{\prime \prime} \mathrm{W}$ & 688 & 10 to 100 & private \\
\hline
\end{tabular}

${ }^{1} \mathrm{FS}=$ Forest Service; BLM = Bureau of Land Management; UC = University of California. 
cypress overstory with subdominant whiteleaf manzanita (Arctostaphylos viscida Parry), chamise (Adenostoma fasciculatum Hook. \& Arn.), and leather oak (Quercus durata Jeps.), along with low densities of emergent foothill pine (Pinus sabiniana Douglas ex Douglas) and very sparse herbaceous cover. Most $\mathrm{McNab}$ cypress communities in Butte, Yuba, and Nevada counties in the northern Sierra Nevada possessed an intermittent herbaceous understory of Brainerd's sedge (Carex brainerdii Mack.), but otherwise closely resembled their North Coast Range counterparts. The communities at Ash Creek and High Valley Ridge in Shasta and Lake counties, respectively, each consisted of a nearly continuous McNab cypress overstory at $5 \mathrm{~m}$ to $8 \mathrm{~m}$ height with a continuous graminoid understory. At the River Pines population in Amador County, McNab cypress generally ranged in height from $6 \mathrm{~m}$ to $11 \mathrm{~m}$, forming an intermittent overstory above an intermittent layer of whiteleaf manzanita, chamise, and wedgeleaf ceanothus (Ceanothus cuneatus [Hook.] Nutt.), with a sparse herbaceous understory. Most stands also possessed a robust geophyte flora including species from the following genera: Allium L., Brodiaea Sm., Calochortus Pursh, Chlorogalum Kunth, Dichelostemma Kunth, Erythronium L., Fritillaria L., Lomatium Rof., Pedicularis L., and Zigadenus Michx.

\section{Age Structure}

Stand age structures were inferred from tree age distributions developed separately for each of 54 plots from $20 \mathrm{McNab}$ cypress populations using tree-ring data from increment cores and stem cross-sections representing a total of 640 individuals. The number of plots surveyed per population $($ mean $=2.7$, range $=$ 1 to 7) depended on population extent and internal heterogeneity. Large or heterogeneous populations were stratified into as many as five stands, with each stand receiving one random- ly located plot. Small populations $(<1$ ha) with uniform topography and internally consistent physiognomy received only one randomly located plot. Stands that had recently burned and possessed both living seedlings and standing snags (i.e., dead parents) were sampled with two plots, one for each generation. All plots were rectangular (width:length $=1: 10$ ) and sized to include 10 to 20 living McNab cypress stems $\left(\right.$ mean plot size $=93 \mathrm{~m}^{2}$, range $=$ $22.5 \mathrm{~m}^{2}$ to $1000 \mathrm{~m}^{2}$ ). I used long, narrow plots because this improved my ability to detect fine-grain spatial heterogeneity in age structure that could result from treefall-driven gap dynamics or patchy fire effects (Barbour et al. 1998, McCune and Grace 2002). Sampling intensity within plots was kept relatively low in order to facilitate the sampling of more stands per population.

Within each plot, the location, overall height, and diameter at $30 \mathrm{~cm}$ height were recorded for each living McNab cypress individual. All living trees greater than $4.0 \mathrm{~cm}$ diameter at $30 \mathrm{~cm}$ height were cored to pith at that height. If the initial coring attempt failed to provide an adequate sample, a maximum of two additional cores were extracted within several centimeters of the first. If, due to rot or eccentric radial growth, a core containing pith still could not be obtained, the core reaching closest to pith was kept and the others discarded. All trees smaller than the $4.0 \mathrm{~cm}$ diameter at coring height, or a haphazard subsample thereof, were felled and basal sections of the stems were collected for dating. Plots within stands that had recently experienced stand-replacing fire were sampled by collecting basal sections from all burned snags within the plot and from a random subsample of any living seedlings.

Dates of establishment for small-diameter trees and burned snags were obtained by cutting a disc from the basal end (i.e., root crown) of each stem sample, then sanding and crossdating the basal surface following standard 
procedures (Stokes and Smiley 1968). Cores were similarly sanded and cross-dated after being dried and glued to wooden mounts. Cross-dating was primarily performed among samples within plots because ring-width variation in $\mathrm{McNab}$ cypress correlated poorly with existing chronologies derived from other species at higher elevations. For cores that did not reach pith $(32 \%)$, the number of missed rings were estimated using cumulative radial growth curves developed separately for each plot following a variation of the technique given by Villalba and Veblen (1997). Cores that were estimated to have missed the pith by more than $1 \mathrm{~cm}$ were not used in subsequent analyses.

Pith dates from cores were transformed into establishment dates using an empirically derived relationship between radial and vertical rates of stem growth. Specifically, for all basal stem sections collected from snags in plots within recently burned stands, mean cumulative radius of the five innermost annual rings at $30 \mathrm{~cm}$ height was plotted against the time taken to grow to $30 \mathrm{~cm}$ height (JMP 5.0.1; SAS Institute, Cary, North Carolina, USA). The resulting linear correlation $(r=0.73, n=$ $41, P \leq 0.001$; time to reach $30 \mathrm{~cm}$ height [yr] $=8.269$ [yr] -0.849 [yr per mm] $\times$ five-year radius at $30 \mathrm{~cm}$ height [mm]) was used to calculate an estimate of the time taken to reach 30 $\mathrm{cm}$ height for each tree in the study from which a complete core had been obtained. These times were then subtracted from their respective core pith dates to estimate dates of establishment (i.e., [tree establishment date] $=$ [pith date from core] - [time to reach $30 \mathrm{~cm}$ height]). For cores that lacked pith, within-plot averages of these times were subtracted from the inferred pith dates to determine dates of establishment. Once establishment dates had been determined for all individuals within a plot, dates were grouped into $10 \mathrm{yr}$ classes (e.g., 1900 to 1909), plotted as frequency distributions, and visually evaluated (Veblen 1992).
Plots exhibiting unimodal frequency distributions were classified as even-aged, and those exhibiting diffuse distributions were classified as uneven-aged.

Stem density, mean tree diameter, and mean tree height were compared between even- and uneven-aged plots using $t$-tests (JMP 5.0.1) after stem densities and tree heights were logtransformed to satisfy assumptions of normality. Mean tree diameters and mean tree heights were calculated for each plot using only the upper fiftieth percentile values in order to focus attention on mature individuals. Immature stands (i.e., even-aged stands that established on or after 1992) were completely excluded from the analysis for the same reason.

\section{Fire History}

Field observations and statewide fire records were used to interpret variation in age structure with respect to historic fire regime. The recent history of fire occurrence was evaluated within and around each plot by noting the presence or absence of burned snags, external fire scars on living trees, and charred material on the ground. Independently, dates of fire occurrence in $\mathrm{McNab}$ cypress populations since approximately 1900 were obtained by overlaying the California digital geodatabase of fire perimeters (California Department of Forestry and Fire Protection [CDF] 2008) onto mapped $\mathrm{McNab}$ cypress locations in a geographic information system (GIS). In several cases, supplemental information on fire and land-use history was provided by land owners or local agency staff.

To determine if fire was the primary cause of stand replacement, I compared locations and dates of tree establishment in even-aged stands originating on or after 1950 with fire records for the same period. Spatiotemporal correspondence between pulses of tree establishment and fire events were assessed qualitatively with the expectation that if even-aged stand 
structures resulted from fire, recruitment should approximately postdate the record of fire occurrence by a single year. Similar comparisons were performed to determine if lowor moderate-severity fires were involved in the development of uneven-aged stands. Unevenaged plots containing trees that established on or after 1950 were evaluated in the context of fire records and field observations, and if no evidence of recent fire existed for these stands, I concluded that any recent recruitment in these uneven-aged stands had occurred in the absence of fire. The year 1950 was used as a cutoff for these comparisons because the completeness of the fire record degrades substantially prior to that date.

Precise dates of stand-replacing fires were estimated separately for each even-aged plot by subtracting one year from the mean establishment date for constituent trees. I performed ANOVAs $(\alpha=0.05)$ and Tukey's multiple comparison procedure (JMP) as necessary in order to ascertain the number of distinct fire events in situations where nearby stands displayed similar yet not identical fire dates that may have been caused by the same fire. Dates derived from tree-ring analysis were plotted by decade along with dates obtained from fire records (CDF 2008) in order to evaluate the temporal pattern of fire occurrence.

\section{RESULTS}

\section{Age Structure}

Of the 54 plots surveyed, 49 exhibited unimodal age distributions indicative of evenaged stands (Figures 1, 2, and 3). Tree ages within the remaining five plots were highly dispersed and indicative of uneven-aged stands. Specifically, the mean standard deviation for tree ages within even-aged plots was 5 $\mathrm{yr}$ (range $=0 \mathrm{yr}$ to $19 \mathrm{yr}$ ), whereas the mean standard deviation for tree ages within unevenaged plots was $67 \mathrm{yr}$ (range $=28 \mathrm{yr}$ to $98 \mathrm{yr}$ ).
Uneven-aged stands consisted primarily or exclusively of trees that recruited prior to 1882 . No evidence of tree recruitment was observed in uneven-aged stands for the subsequent nine decades, but the presence of young individuals within three uneven-aged plots (Ash Creek, Indiana Creek, River Pines) indicated that recruitment had occurred in those stands on multiple occasions since at least the 1970s.

Most McNab cypress populations (80\%) consisted entirely of even-aged stands, but populations at Ash Creek, Indiana Creek, Magalia, and River Pines consisted of both evenand uneven-aged stands (Figure 1). Field observations indicated that most of the River Pines population consisted of uneven-aged stands, but uneven-aged stands were only minor components of the Ash Creek, Indiana Creek, and Magalia populations. All four populations containing uneven-aged stands were located within the eastern portion of the species' range, including the northern Sierra Nevada and southern Cascade Range.

Plots from even- and uneven-aged stands differed with respect to maximum tree age, stem density, and tree size. The earliest date of establishment observed for any even-aged plot was approximately 1800 , yet most uneven-aged plots $(80 \%)$ contained trees that were recruited prior to this date. Also, the mean maximum tree age for uneven-aged plots was more than double the mean maximum tree age found for even-aged plots (229 yr vs. 99 yr). Stem densities in uneven-aged plots were significantly lower than those in even-aged plots $\left(t_{47}=6.72\right.$, $P \leq 0.001)$, while stem diameters and tree heights were higher (diameter: $t_{4}=4.84, P=$ 0.007; height: $t_{47}=2.86, P=0.006$ ) (Figure 4).

\section{Fire History}

Nine plots were sampled from even-aged stands that originated on or after 1950 in the following populations: Concow, Indiana Creek, Knoxville, Lake Mildred, Montgomery Creek, 


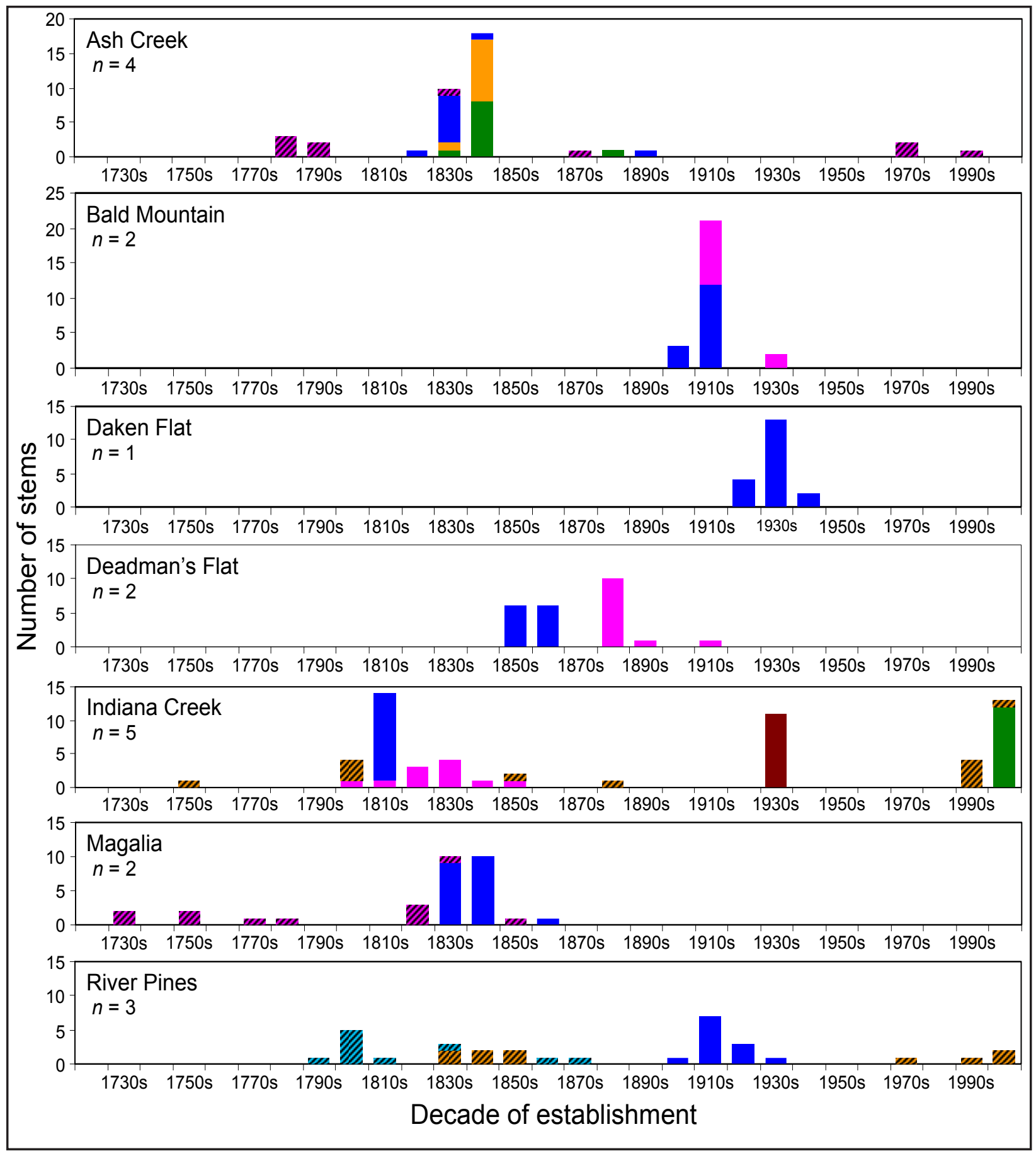

Figure 1. Age structures for 19 of the 23 plots sampled from $10 \mathrm{McNab}$ cypress populations in the northern Sierra Nevada and southern Cascade Range. Age structures for plots sampled at Concow, Lake Mildred, and Montgomery Creek are shown in Figure 3. Colors distinguish different plots representing different stands within the same population. Solid colors show even-aged plots, bars with diagonal stripes show uneven-aged plots. Names of populations and the number of plots sampled $(n)$ within each population are displayed in the upper left corner of each histogram. 


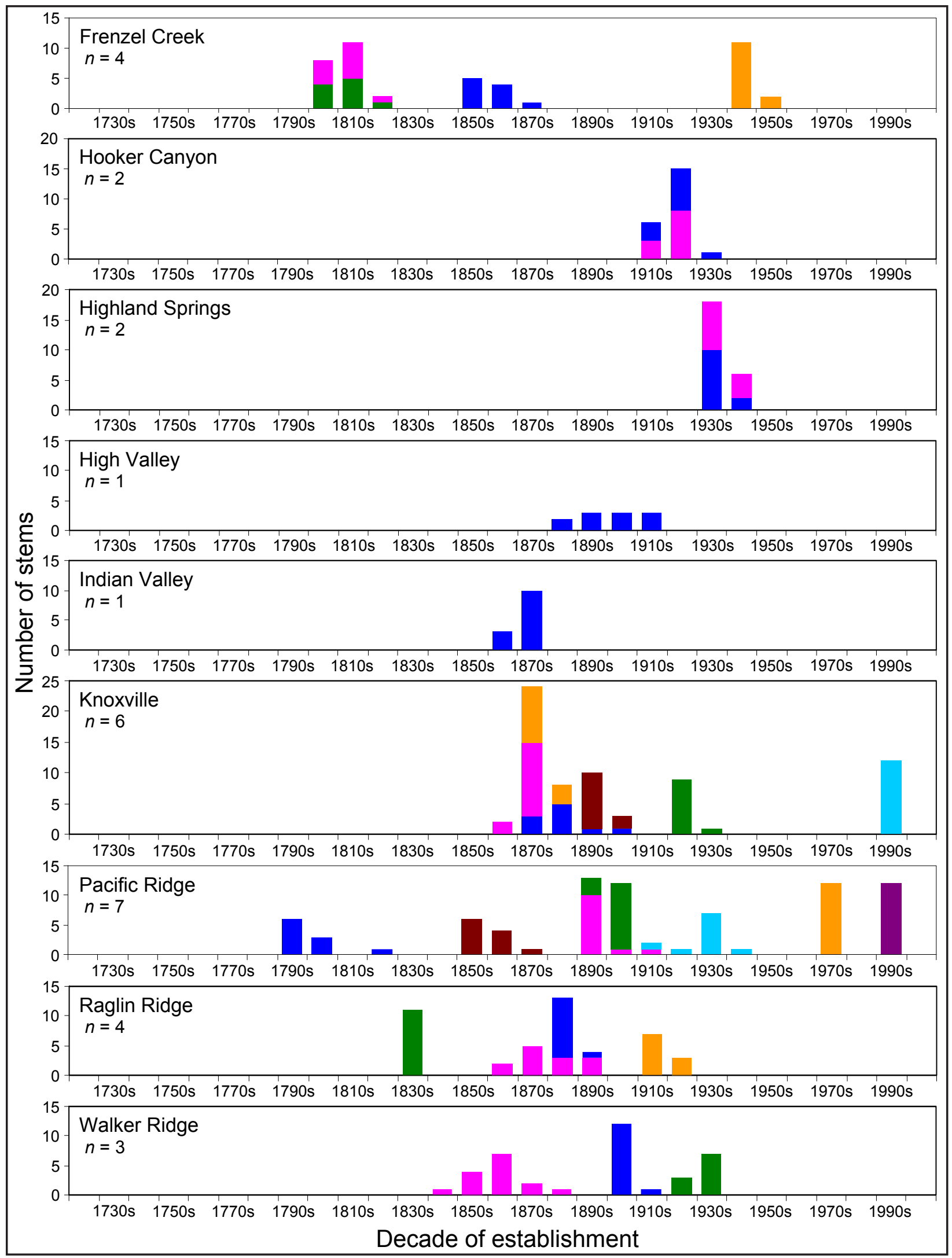

Figure 2. Age structures for 30 of the 31 plots sampled from $10 \mathrm{McNab}$ cypress populations in the North Coast Range. Age structure for the plot sampled at Palisades is shown in Figure 3. See Figure 1 for additional details regarding interpretation. 


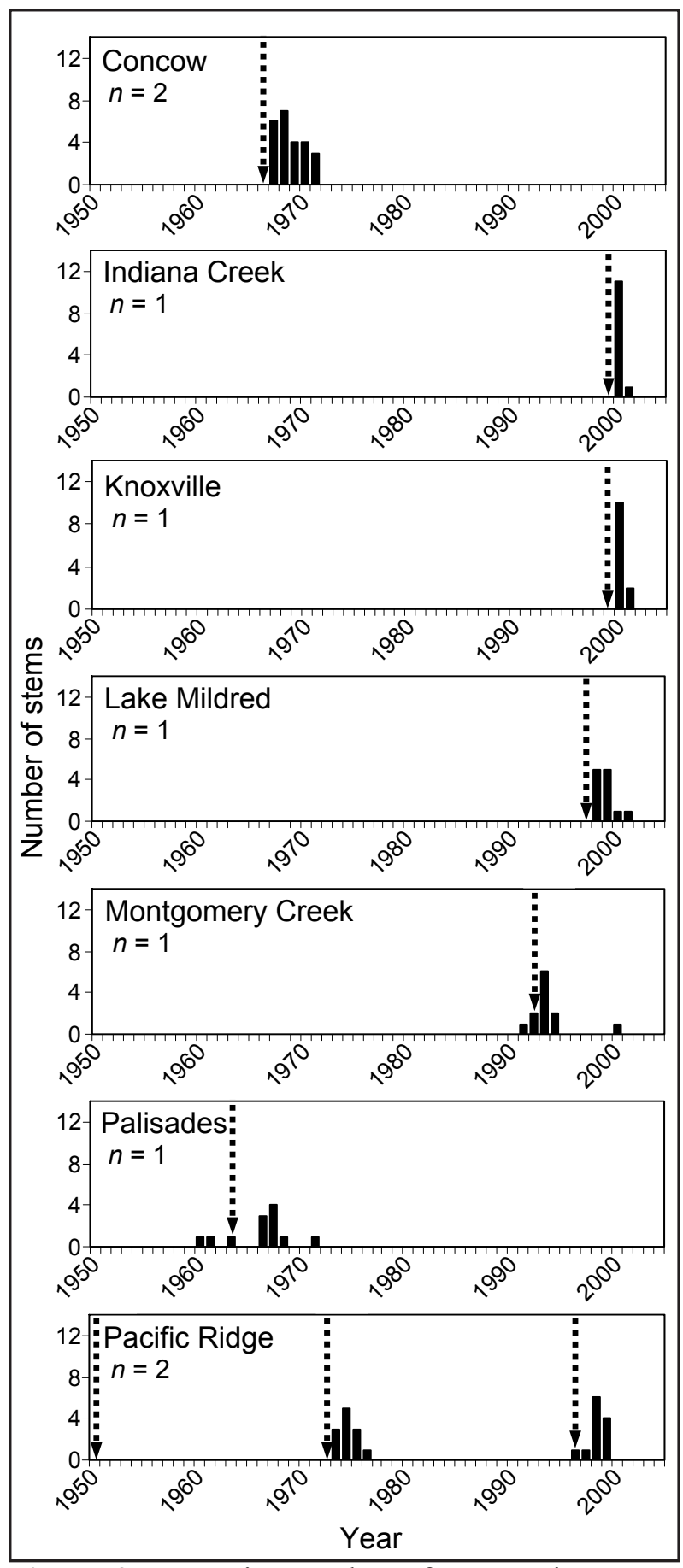

Figure 3. Recruitment dates for McNab cypress within even-aged stands that originated on or after 1950 and prior to 2008 (solid bars), and dates of fire occurrence at each location for the same time period (dashed arrows). Recruitment dates inferred from tree-rings. Fire dates obtained from either fire records or a combination of agency documents and cross-dated scars. Names of populations are in upper left corner of each histogram along with the number $(n)$ of plots from each population for which data are displayed.

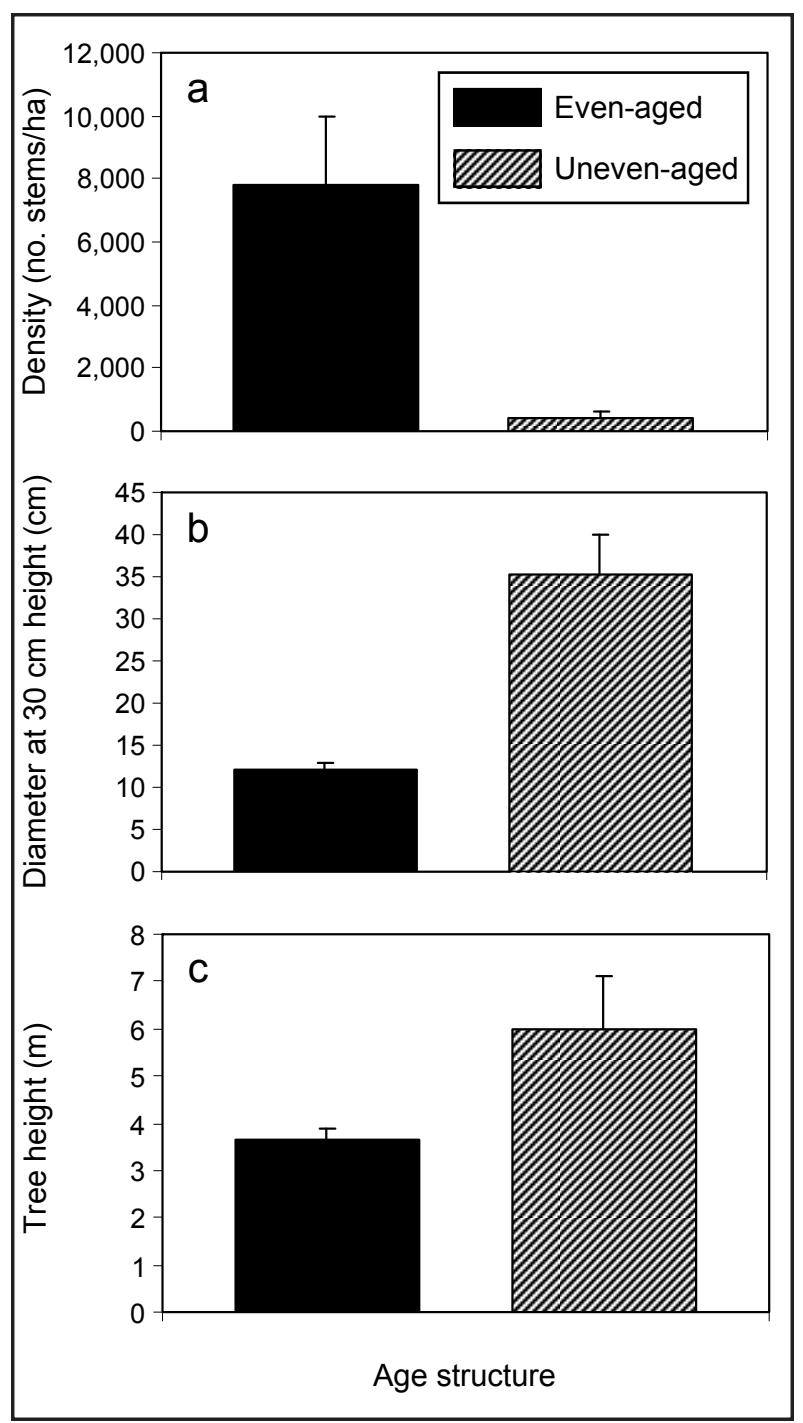

Figure 4. The (a) stem density (mean $+\mathrm{SE})$, (b) stem diameter at $30 \mathrm{~cm}$ height (mean $+\mathrm{SE})$, and (c) height (mean $+\mathrm{SE}$ ) of mature $\mathrm{McNab}$ cypress individuals within plots dominated by mature trees. The data shown are not transformed. Solid bars show even-aged plots, diagonally striped bars show uneven-aged plots.

Pacific Ridge, and Palisades. For all nine plots, establishment dates inferred from treering analysis corresponded closely with dates of fires obtained from fire records or from likely fire dates derived from a combination of agency documents and field observations (Figure 3). Specifically, recruitment at eight of the nine even-aged plots coincided with dates obtained from the fire perimeter database (CDF 2008) for the following fires: Concow Road 
Two Fire (Concow, 1966), Pendola Fire (Indiana Creek, 1999), Sixteen Fire (Knoxville, 1999), Williams Fire (Lake Mildred, 1997), Fountain Fire (Montgomery Creek, 1992), Fork Fire (Pacific Ridge, 1996), and C. Hanly Fire (Palisades, 1964). One potential exception to this trend was found at Pacific Ridge where a recruitment episode in the 1970 s postdated recorded fire occurrence by almost 25 years. However, agency documents (R. Mowery, Forest Service, personal communication) and cross-dated scars on nearby trees indicated that a relatively small fire may have been implemented by the Forest Service at Pacific Ridge in 1972 as part of a type-conversion project, and it is unlikely that the fire would have been entered into the fire perimeter database. In addition, dates of establishment for even-aged stands at Hooker Canyon were consistent with Wolf's (1948) description of the site in 1934 in which he noted evidence of a recent fire (Figure 4).

With the exception of the four trees at $\mathrm{Pa}$ cific Ridge mentioned above, basal scars were completely absent from trees in all populations. Seven of the nine plots that established on or after 1950 also contained evidence of recent fire in the form of charred stumps or logs. Charred logs were also found near the only even-aged plot sampled at the River Pines population. In contrast, no evidence of recent fire was found for any of the three unevenaged plots in which tree establishment had occurred on or after 1950.

Data from tree-rings and fire records provided dates of 44 stand-replacing fires that occurred as far back as 1799 and as recently as 2008 (Figure 5). Only five fires occurred in the surveyed McNab cypress populations during the five decades between 1940 and 1989 (mean $=1$ fire per decade), a period for which both sources of fire dates were essentially complete. In contrast, 26 stand-replacing fires were detected in McNab cypress stands during the preceding $100 \mathrm{yr}$ period (1839 to 1939 , mean $=$

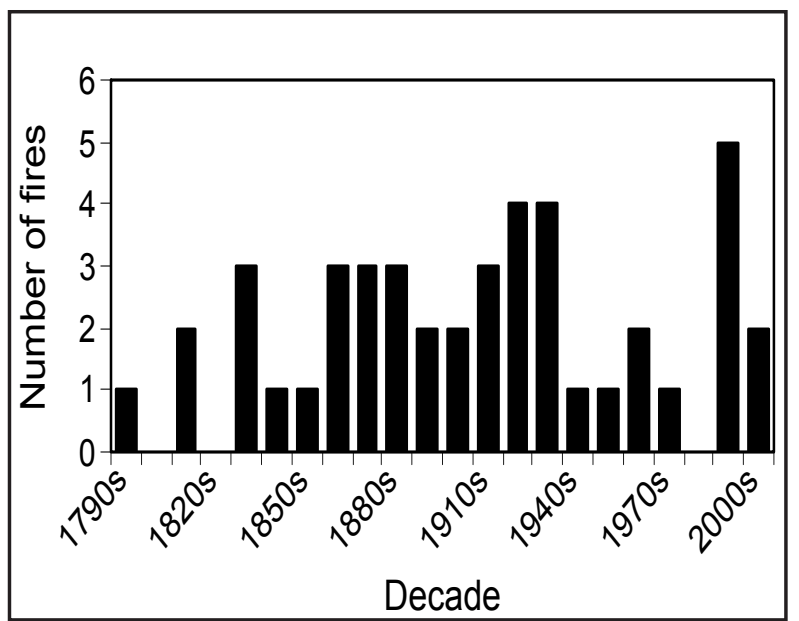

Figure 5. The number of stand-replacing fires detected in McNab cypress populations using stand recruitment dates, the California geodatabase of fire perimeters, and, in one case, a combination of agency documents and cross-dated tree scars. Recruitment dates were derived from tree-ring samples obtained between 2006 and 2009. The fire records spanned the period between 1928 and 2009.

2.6 fires per decade), and 7 stand-replacing fires occurred during the $20 \mathrm{yr}$ that followed (1990 to 2009, mean $=3.5$ fires per decade).

\section{DISCUSSION}

The preponderance of even-aged stands relative to uneven-aged stands, and the synchrony between stand establishment and fire occurrence collectively provide strong empirical support for the idea that $\mathrm{McNab}$ cypress populations have primarily been maintained by stand-replacing fires. However, a minority of stands displayed uneven age structures, indicating that recruitment of $\mathrm{McNab}$ cypress may not be as dependent on stand-replacing fire as is commonly assumed for serotinous plants. Also, uneven-aged stands generally contained trees that were older, larger, and at lower densities than those in even-aged plots. When aggregated, the dates of stand-replacing fires (derived from stand recruitment dates and fire records) revealed that relatively few stand-replacing fires occurred in McNab cypress populations during the $50 \mathrm{yr}$ period between 1940 
and 1989 compared to either the previous 100 $\mathrm{yr}$ period or the subsequent $20 \mathrm{yr}$ period.

The results presented here are consistent with observations made within recently burned stands at Concow, Indiana Creek, Knoxville, Lake Mildred, Montgomery Creek, Pacific Ridge, and Walker Ridge following the BTU Lightning Complex (2008), Pendola Fire (1999), Sixteen Fire (1999), Williams Fire (1997), Fountain Fire (1992), Fork Fire (1996), and Walker Ridge Fire (2008), respectively. Characteristics of newly burned sites typically included (1) distinct burn perimeters, (2) uniformly high mortality for nonsprouting woody species, and (3) dense McNab cypress recruitment near burned snags (C.R. Mallek, unpublished data) (Figure 6). Moderate- or low-severity fire effects were rarely observed, and only as occasional narrow strips along burn perimeters, or as small unconsumed islands near obvious discontinuities in fuel quantity and structure such as prominent rock outcrops. Recent stand-replacing fires have also been reported in populations of two other cypress species in the CFP: Sargent cypress (Hesperocyparis sargentii [Jeps.] Bartel) (Ne'eman et al. 1999) and Tecate cypress (H. forbesii [Jeps.] Bartel) (Zedler 1981, Dunn 1984). In a study of Tecate cypress, de Gouvanain and Ansary (2006) found "some populations exhibiting uneven-aged structure," but limited reporting of their methods and results precludes interpretation of this statement in the context of fire history.

While there was no systematic attempt to define the extent of stand-replacing fires using tree ages in this study, several lines of evidence indicate that stand-replacing fires in $\mathrm{McNab}$ cypress often affect broad areas much larger than the sizes of the plots used here. First, in all populations that burned between 1992 and 2008 , the amount of area visibly affected by stand-replacing fires exceeded $\approx 5 \mathrm{ha}$, and in two cases (Montgomery Creek, Lake Mildred) stand-replacing fires nearly burned entire pop-

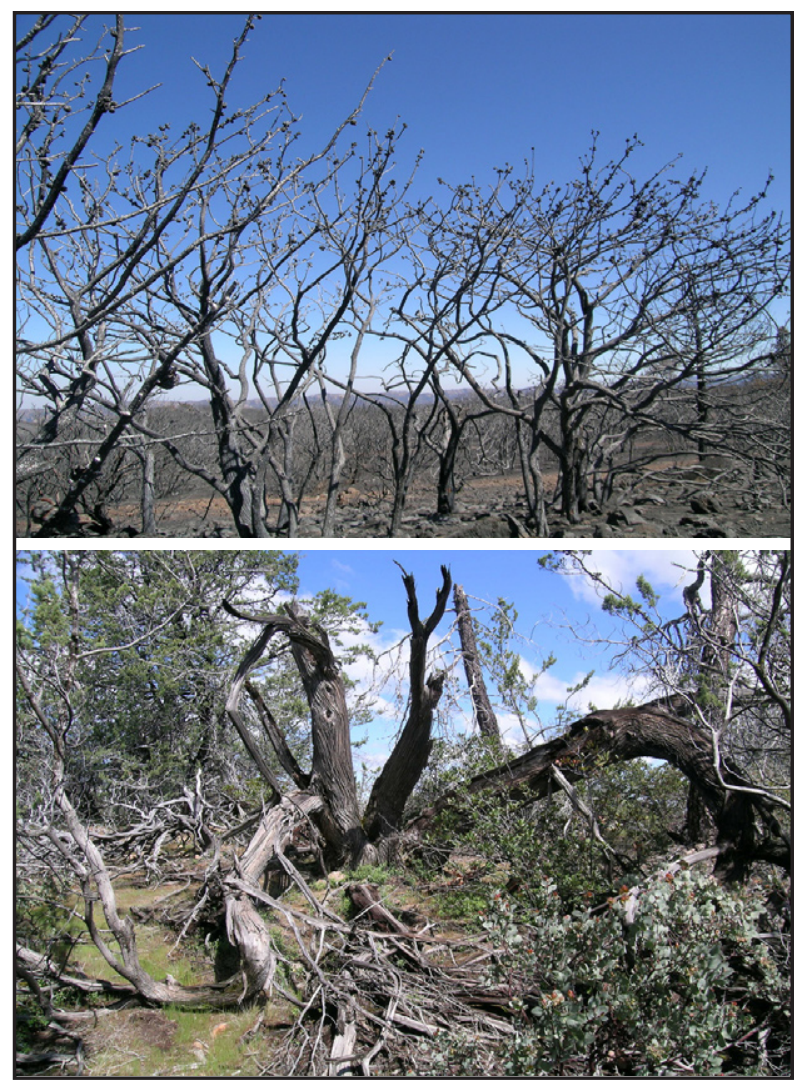

Figure 6. McNab cypress recruitment was associated with either of two processes: stand-replacing fire, or structural failure and senescence of old, large trees. (Top) McNab cypress population at Walker Ridge two days after stand-replacing fire. (Bottom) Structural failure of a large, multi-stemmed $\mathrm{McNab}$ cypress individual in a low-density stand at the River Pines population.

ulations. Second, as part of a separate study, tree-ring data were obtained from small numbers of randomly chosen individuals (12 to 17 individuals per population) within a subset (13) of the populations surveyed in this study, and preliminary age estimates for those individuals generally corresponded closely with establishment dates for trees within the nearest even-aged plots (C.R. Mallek, unpublished data). Third, in eight populations, trees within separate even-aged plots belonged to the same cohort despite attempts to disperse plots as widely as possible within populations.

In order to correctly interpret uneven plotlevel age structures in the context of fire history, three alternative explanatory scenarios must 
be considered. First, uneven age structure may be an artifact of placing plots across the perimeters of past stand-replacing fires. Second, uneven-aged plots may represent a series of cohorts that recruited following moderate-severity fires that generated fine-grain spatial heterogeneity in tree ages. Third, uneven-aged plots could develop through low-level recruitment during prolonged fire-free periods. In this study, uneven-aged plots were most likely not artifacts of sampling across the perimeters of past stand-replacing fires because (1) plots were placed only within areas exhibiting internally consistent physiognomy, (2) spatial autocorrelation in tree ages was weak, and (3) age distributions were clearly not bimodal. Although recruitment has occurred without fire during recent decades in three of the five uneven-aged plots, pinpointing the cause of uneven age structures that existed prior to 1970 would require larger sample sizes than those employed in this study. Nevertheless, these findings question the common view of serotiny in which successful regeneration is thought to depend entirely on stand-replacing fire.

For any plant, successful establishment from seed occurs when seed availability and the availability of establishment opportunities coincide in space and time. Stand-replacing fires in $\mathrm{McNab}$ cypress stands lead to widespread and rapid cone opening, followed by intense seed rain and dense seedling recruitment. However, in contrast to the cones of serotinous pines that also open following intense crown fires, $\mathrm{McNab}$ cypress cones consist of living tissue and the proximal cause of cone opening is generally tissue death and subsequent desiccation rather than exposure to heat (C.R. Mallek, unpublished data). This mechanism of cone-opening has been reported for other serotinous members of the Cupressaceae (Harvey et al. 1980, Zedler 1986, Lev-Yadun 1995, Garcillan 2010). Consequently, storm damage, cone-boring insects, pathogens, and old age may contribute to either the death of entire trees, individual branches, or isolated cones resulting in inter-fire cone opening followed by low levels of seed dispersal. In many stands, destruction of living cones by birds, perhaps as a means of foraging for cone-boring insects, may also result in the release of small quantities of seed (C.R. Mallek, personal observation).

Seed dispersal, however, is unlikely to lead to successful establishment if seeds germinate under a closed canopy. First-year McNab cypress seedlings frequently appear at low densities in unburned stands starting in the late winter of each year. Under closed-canopy conditions, these seedlings typically experience complete mortality during their first summer, but successful recruitment sometimes occurs where fire or individual treefalls have created gaps in the overstory vegetation. Similar spatial patterns of recruitment in the absence of fire were recently documented for Guadalupe cypress (Hesperocyparis guadalupensis [S. Watson] Bartel) (Garcillan et al. 2009). $\mathrm{McNab}$ cypress possesses several traits that predispose larger trees to structural failure, including weak branch attachment and poor resistance to decay (C.R. Mallek, personal observation; Harris et al. 2004) (Figure 6). Uneven-aged plots generally contained the oldest and largest trees and exhibited the highest rates of structural failure for all plots surveyed. This suggests that the long-term absence of standreplacing fire permits trees to attain extremes of age and size and that these attributes increase the likelihood of structural failure and adult tree mortality, which in turn facilitate successful inter-fire establishment. Importantly, although multiple factors can lead to either seed dispersal or gap generation independently, inter-fire tree mortality and structural failure best explain inter-fire recruitment because they satisfy both prerequisites for successful establishment simultaneously.

Wolf's (1948) description of the River Pines population is consistent with this theory 
of inter-fire establishment. Following his visit to the River Pines population in 1934 (referred to as "Aukum" by Wolf), he similarly noted the presence of McNab cypress seedlings despite the lack of evidence of recent fires. As noted above, seedlings rarely survive the first summer dry period under closed-canopy conditions, so the fact that Wolf (1948) observed living seedlings in October (the end of the dry period) suggests that they germinated under open conditions. Moreover, Wolf's comments on the abundance of "over-mature or decadent trees," their "extreme size," and "numerous broken branches" support the idea that senescence and structural failure of large trees is the primary gap-generating mechanism involved in inter-fire establishment.

Four of the five uneven-aged plots exhibited uneven age structure prior to 1890 , suggesting that uneven age structures may be typical features at these locations rather than recent byproducts of changes in land use, land management, or climate. Mechanistically, this is plausible because the discontinuity in canopy fuel structure associated with low stem densities may inhibit the spread of stand-replacing fires, and the relatively rapid growth of opengrown trees may further increase the likelihood that they will succumb to structural failure rather than fire. The relatively low seedling densities that seem to characterize inter-fire recruitment may then serve to maintain or prolong an open vegetation structure. This seems particularly likely for the River Pines population due to the similarities between Wolf's (1948) description of the population in 1934 and current observations made in the same population. Moreover, the facts that unevenaged stands contained the oldest individuals currently known to exist, and that these stands were found exclusively in the eastern portion of the species' range, suggest that the factors responsible for the long-term absence of standreplacing fire include a geographically correlated component.
Aggregated dates of fire occurrence may reflect recent shifts in fire return intervals for the species as a whole. The disparity between the mean number of detected fires per decade for the $100 \mathrm{yr}$ prior to 1940 (2.6 fires per decade) versus that for the $50 \mathrm{yr}$ after 1940 (1 fire per decade) is particularly striking given the comparative completeness of the record for the latter period. Dendrochronology sampling methods for landscapes prone to stand-replacing fires are inherently biased toward detection of recent fires. Thus, if fire sizes and specieswide rates of fire occurrence had remained constant, evidence of stand-replacing fires should generally be more abundant for later periods of time. The fact that the results presented here exhibit the opposite pattern suggests that a shift in the mean fire return interval for the species occurred in the 1940s and lasted for about $50 \mathrm{yr}$.

Possible explanations for the $50 \mathrm{yr}$ gap in fire occurrence include fire management and climate change. The sudden reduction in fire occurrence coincided with both the advent of effective fire suppression in the region (Pyne et al. 1996, Stuart and Stephens 2006) and a transition from one of the region's driest periods of the last millennium (1915 to 1934) to one of the region's wettest (1937 to 1986) (Graumlich 1993). In addition, the resurgence of fire activity in McNab cypress populations in the early 1990s roughly coincided with an increase in the frequency of large fires in forested areas of northern California as well as recent trends of earlier snowmelt and longer fire season across the western United States (Westerling et al. 2006).

These results have important management implications. Extreme variation in fire return intervals may threaten populations of serotinous plants in either of two ways: short intervals may kill plants prior to reproductive maturity or the accumulation of a seed bank sufficient for postfire stand replacement, and long intervals may allow populations and their seed 
banks to senesce (Zedler 1981, Dunn 1984). Tecate cypress, which occurs in the southern CFP, has recently suffered population declines and local extinctions following excessively short fire return intervals (Zedler 1981). However, this does not seem to be the case for $\mathrm{McNab}$ cypress. Although it is unclear how much time is necessary for $\mathrm{McNab}$ cypress stands to accrue a seed bank sufficient for postfire replacement, most individuals tend to begin producing seed between $10 \mathrm{yr}$ and $20 \mathrm{yr}$ of age (C.R. Mallek, personal observation). Thus, given that $90 \%$ of the surveyed populations consist entirely or primarily of cohorts that have not experienced fire in over $40 \mathrm{yr}$ (i. e., age of maturation $\times$ two), short fire return intervals are probably not a significant threat to species persistence at this time, so there is little ecological justification for fire exclusion. Evidence suggests that fire return intervals are now, on average, longer than they were historically, but some stands have demonstrated a capacity to establish new individuals even in the absence of fire. Thus, it may be that there is no immediate need to begin applying fire to older McNab cypress stands. As Zedler (1995) suggested, the risks associated with allowing vegetation to age beyond historic levels seems to be less acute than those associated with shortened fire intervals.

Importantly, however, four arguments caution against the exclusion of fire from $\mathrm{McNab}$ cypress populations indefinitely. First, the importance of stand-replacing fires for the longterm persistence of $\mathrm{McNab}$ cypress is strongly supported by the historical prevalence of such fires across the species' entire range over the last several centuries. Second, it is unclear if inter-fire recruitment is sufficient to sustain $\mathrm{McNab}$ cypress populations and communities for fire-free periods lasting longer than several generations. Third, although some stands have demonstrated the ability to establish new individuals in the absence of fire, the extent to which the genetic and environmental character- istics of other stands could permit similar interfire recruitment remains unknown. Finally, prolonged fire-free periods may permit invasion by taller, prolific, fire-sensitive species such as foothill pine (McCarten and Rogers 1991).

Stand-replacing fires may also enhance the viability of $\mathrm{McNab}$ cypress populations indirectly by regulating populations of parasitic plants (e.g., mistletoe [Phoradendron densum Torr. Ex Trel.]) and cone-boring insects that can adversely affect tree growth, survival, and reproductive output (Kipfmueller and Baker 1998; Geils et al. 2002; Parker et al. 2006; C.R. Mallek, unpublished data). In addition, for most shrubs commonly associated with McNab cypress (e.g., whiteleaf manzanita, chamise, wedgeleaf ceanothus), germination rates are increased by exposure to high temperatures, charate, or increased light (Keeley 1987, 2007). Stand-replacing fires may also be important for maintaining the geophyte flora of $\mathrm{McNab}$ cypress communities. In southern California, Tyler and Borchert (2003) and Borchert and Tyler (2009) reported that flowering and seed production for death camas ( $\mathrm{Zi}$ gadenus fremontii [Torr.] Torr. ex S. Watson) and soap plant (Chlorogalum pomeridianum [DC.] Kunth) were intense in the first year following stand-replacing fire in chaparral vegetation, yet rare in both adjacent unburned areas and during the subsequent nine years at the burned sites. Consequently, fires of this type potentially not only enhance reproductive output, but they may also play an important role in promoting gene flow within the diverse geophyte flora of $\mathrm{McNab}$ cypress communities by synchronizing rare flowering events across large areas.

Observations in recently burned stands suggest that stand-replacing fires within $\mathrm{McNab}$ cypress populations typically take the form of high-intensity crown fires. However, high-intensity crown fires might not be necessary to result in stand-replacement. For ex- 
ample, Waldrop et al. (2006) found that a surface fire of moderate intensity was sufficient to achieve stand-replacement in communities dominated by a serotinous pine (Table Mountain pine) in the Appalachian Mountains of eastern North America. Given the close proximity of most $\mathrm{McNab}$ cypress populations to human residences and the likelihood of continued wildfire suppression in these areas, land managers may increasingly look to prescribed burning as a means of maintaining these populations and the communities that they dominate. If so, the type and intensity of fire required to produce stand-replacement will need to be defined because high-intensity prescribed fires may be impractical for maintaining the many $\mathrm{McNab}$ cypress populations that exist within expanding zones of wildland-urban interface and intermix in northern California.

\section{ACKNOWLEDGEMENTS}

This research was funded by the University of California, Davis, Department of Plant Sciences; USDA Forest Service; California Native Plant Society, Santa Clara Chapter; and Davis Botanical Society, Jack Major Memorial Research Grant. Many agencies and private entities generously granted access to field sites including the Plumas and Mendocino National Forests; Ukiah and Folsom Districts of the Bureau of Land Management; University of California McLaughlin Reserve; Paradise Irrigation District; Wild Horse Sanctuary; as well as the Bennett, Cady, Dickie, Livermore, Molloy, and Morales families. Special thanks to H. Safford for suggesting McNab cypress as a research topic; and to the Forest Service, Pacific Southwest Research Station, Silviculture Laboratory for technical assistance with dendrochronology methods. This paper benefited from comments provided by C. Dolanc, K. Rice, H. Safford, T. Swetnam, P. Zedler, and one anonymous reviewer.

\section{LITERATURE CITED}

Adams, R.P., J.A. Bartel, and R.A. Price. 2009. A new genus, Hesperocyparis, for the cypresses of the western hemisphere (Cupressaceae). Phytologia 91: 160-185.

Barbour, M.G., J.H. Burk, W.D. Pitts, F.S. Gilliam, and M.W. Schwartz. 1998. Terrestrial plant ecology. Third edition. Addison Wesley Longman, Menlo Park, California, USA.

Beaty, R.M., and A.H. Taylor. 2009. A 14,000 year sedimentary charcoal record of fire from the northern Sierra Nevada, Lake Tahoe Basin, California, USA. The Holocene 19: 347-358.

Benkman, C.W., and A.M. Siepielski. 2004. A keystone selective agent? Pine squirrels and the frequency of serotiny in lodgepole pine. Ecology 85: 2082-2087.

Bond, W.J. 1985. Canopy-stored seed reserves (serotiny) in Cape Proteaceae. South African Journal of Botany 51: 181-186.

Borchert, M. 1985. Serotiny and cone-habit variation in populations of Pinus coulteri (Pinaceae) in the southern Coast Ranges of California. Madroño 32: 29-48.

Borchert, M., and C.M. Tyler. 2009. Patterns of post-fire flowering and fruiting in Chlorogalum pomeridianum var. pomeridianum (DC.) Kunth in southern California chaparral. International Journal of Wildland Fire 18: 623-630.

Brose, P.H., and T.A. Waldrop. 2006. Fire and the origin of Table Mountain pine-pitch pine communities in the southern Appalachian Mountains, USA. Canadian Journal of Forest Research 36: 710-718. 
California Department of Forestry and Fire Protection [CDF]. 2008. Fire and resource assessment program. Fire perimeters version 08_2. <http://frap.cdf.ca.gov/projects/fire_data/fire_ perimeters/>. Accessed 18 Nov 2009.

Clark, J.S. 1996. Testing disturbance theory with long-term data: alternative life-history solutions to the distribution of events. American Naturalist 148: 976-996.

Cowling, R.M., and B.B. Lamont. 1985. Variation in serotiny of three Banksia species along a climatic gradient. Australian Journal of Ecology 10: 345-350.

de Gouvenain, R.C., and A.M. Ansary. 2006. Association between fire return interval and population dynamics in four California populations of Tecate cypress (Cupressus forbesii). The Southwestern Naturalist 51: 447-454.

Dunn, A.T. 1987. Population dynamics of the Tecate cypress. Pages 367-376 in: T.S. Elias, editor. Conservation and management of rare and endangered plants. California Native Plant Society, Sacramento, California, USA.

Ellison, A.M., M.S. Banks, B.D. Clinton, E.A. Colburn, K. Elliott, C.R. Ford, D.R. Foster, B.D. Kloeppel, J.D. Knoepp, G.M. Lovett, J. Mohan, D.A. Orwig, N.L. Rodenhouse, W.V. Sobczak, K.A. Stinson, J.K. Stone, C.M. Swan, J. Thompson, B. Von Holle, and J.R. Webster. 2005. Loss of foundation species: consequences for the structure and dynamics of forested ecosystems. Frontiers in Ecology and the Environment 3: 479-486.

Garcillan, P.P. 2010. Seed release without fire in Callitropsis guadalupensis, a serotinous cypress of a Mediterranean-climate oceanic island. Journal of Arid Environments: in press.

Garcillan, P.P., E. Vega, and E. Lopez-Reyes. 2009. Recruitment response of Guadalupe cypress (Callitropsis guadalupensis) three years after goat eradication on Guadalupe Island. Pages 177-183 in: C.C. Damiani, and D.K. Garcelon, editors. Proceedings of the 7th annual California islands symposium. Institute for Wildlife Studies, 5-7 February 2008, Arcata, California, USA.

Gauthier, S., Y. Bergeron, and J. Simon. 1996. Effects of fire regime on the serotiny level of jack pine. Journal of Ecology 84: 539-548.

Geils, B.W., D. Wiens, and F.G. Hawksworth. 2002. Phoradendron in Mexico and the United States. Pages 19-28 in: B.W. Geils, J.C. Tovar, and B. Moody, technical coordinators. Mistletoes of North American conifers. USDA Forest Service General Technical Report RMRS-GTR-98, Fort Collins, Colorado, USA.

Givnish, T.J. 1981. Serotiny, geography, and fire in the pine barrens of New Jersey. Evolution 35: 101-123.

Graumlich, L.J. 1993. A 1,000-yr record of temperature and precipitation in the Sierra Nevada. Quaternary Research 39: 249-255.

Griffin, J.R., and W.B. Critchfield. 1972. The distribution of forest trees in California. USDA Forest Service Research Paper PSW-82, Berkeley, California, USA.

Harris, R.W., J.R. Clark, and N.P. Matheny. 2004. Arboriculture: integrated management of landscape trees, shrubs, and vines. Fourth edition. Prentice Hall, Upper Saddle River, New Jersey, USA.

Harvey, H.T., H.S. Shellhammer, and R.E. Stecker. 1980. Giant sequoia ecology. National Park Service Scientific Monograph Series 12. Washington, D.C., USA.

Hickman, J.C., editor. 1993. The Jepson manual: higher plants of California. University of California Press, Berkeley, USA. 
Keeler-Wolf, T. 2004. Frenzel Creek. Pages 108-111 in: S. Cheng, technical editor. Forest Service Research Natural Areas in California. USDA Forest Service General Technical Report PSW-GTR-188, Albany, California, USA.

Keeley, J.E. 1987. Role of fire in seed germination of woody taxa in California chaparral. Ecology 68: 434-443.

Keeley, J.E. 2007. Chaparral. Pages 339-366 in: M.G. Barbour, T. Keeler-Wolf, and A.A. Schoenherr, editors. Terrestrial vegetation of California. Third edition. University of California Press, Berkeley, USA.

Kipfmueller, K.F., and W.L. Baker. 1998. Fires and dwarf mistletoe in a Rocky Mountain lodgepole pine ecosystem. Forest Ecology and Management 108: 77-84.

Lamont, B.B., D.C. Le Maitre, R.M. Cowling, and N.J. Enright. 1991. Canopy seed storage in woody plants. The Botanical Review 57: 277-317.

Lev-Yadun, S. 1995. Living serotinous cones in Cupressus sempervirens. International Journal of Plant Science 156: 50-54.

Little, D.P. 2006. Evolution and circumscription of the true cypresses (Cupressaceae: Cupressus). Systematic Botany 31: 461-480.

McCarten, N.F., and C. Rogers. 1991. Habitat management study of rare plants and communities associated with serpentine soil habitats in the Mendocino National Forest. USDA Forest Service, Mendocino National Forest, Willows, California, USA.

McCune, B., and J.B. Grace. 2002. Analysis of ecological communities. MjM Software Design, Gleneden Beach, Oregon, USA.

McMaster, G.S., and P.H. Zedler. 1981. Delayed seed dispersal in Pinus torreyana (Torrey pine). Oecologia 51: 62-66.

Millar, C.I., N.L. Stephenson, and S.L. Stephens. 2007. Climate change and forests of the future: managing in the face of uncertainty. Ecological Applications 17: 2145-2151.

Miller, J.D., H.D. Safford, M. Crimmins, and A.E. Thode. 2009. Quantitative evidence for increasing forest fire severity in the Sierra Nevada and southern Cascade Mountains, California and Nevada, USA. Ecosystems 12: 16-32.

Minnich, R.A. 1987. The distribution of forest trees in northern Baja California. Madroño 34: 98-127.

Mohr, J.A., C. Whitlock, and C.N. Skinner. 2000. Postglacial vegetation and fire history, eastern Klamath Mountains, California, USA. The Holocene 10: 587-601.

Myers, N., R.A. Mittermeier, C.G. Mittermeier, G.A.B. da Fonseca, and J. Kent. 2000. Biodiversity hotspots for conservation priorities. Nature 403: 853-858.

Nathan, R., U.N. Safriel, I. Noy-Meir, and G. Schiller. 1999. Seed release without fire in Pinus halepensis, a Mediterranean serotinous wind-dispersed tree. Journal of Ecology 87: 659-669.

Ne'eman, G., C.J. Fotheringham, and J.E. Keeley. 1999. Patch to landscape patterns in post fire recruitment of a serotinous conifer. Plant Ecology 145: 235-242.

Parker, T.J., K.M. Clancy, and R.L. Mathiasen. 2006. Interactions among fire, insects and pathogens in coniferous forests of the interior western United States and Canada. Agricultural and Forest Entomology 8: 167-189.

Pyne, S.J., P.L. Andrews, and R.D. Laven. 1996. Introduction to wildland fire. Second edition. John Wiley and Sons, New York, New York, USA. 
Romme, W. 1980. Fire history terminology: report of the ad hoc committee. Pages 135-137 in: M.A. Stokes and J.H. Dieterich, technical coordinators. Proceedings of the fire history workshop. USDA Forest Service General Technical Report RM-81, Fort Collins, Colorado, USA.

Sawyer, J.O., T. Keeler-Wolf, and J. Evens. 2009. A manual of California vegetation. Second edition. California Native Plant Society, Sacramento, California, USA.

Schoennagel, T., M.G. Turner, and W.H. Romme. 2003. The influence of fire interval and serotiny on postfire lodgepole pine density in Yellowstone National Park. Ecology 84: 29672978.

Schwilk, D.W., and D.D. Ackerly. 2001. Flammability and serotiny as strategies: correlated evolution in pines. Oikos 94: 326-336.

Skinner, C.N., A.H. Taylor, and J.K. Agee. 2006. Klamath Mountains bioregion. Pages 170-194 in: N.G. Sugihara, J.W. van Wagtendonk, K.E. Shaffer, J. Fites-Kaufman, and A.E. Thode, editors. Fire in California's ecosystems. University of California Press, Berkeley, USA.

Stokes, M.A., and T.L. Smiley. 1968. An introduction to tree-ring dating. University of Chicago Press, Illinois, USA.

Stuart, J.D., and S.L. Stephens. 2006. North coast bioregion. Pages 147-169 in: N.G. Sugihara, J.W. van Wagtendonk, K.E. Shaffer, J. Fites-Kaufman, and A.E. Thode, editors. Fire in California's ecosystems. University of California Press, Berkeley, USA.

Sugihara, N.G., J.W. van Wagtendonk, K.E. Shaffer, J. Fites-Kaufman, and A.E. Thode. 2006. Fire in California's ecosystems. University of California Press, Berkeley, USA.

Swetnam, T.W. 1993. Fire history and climate change in giant sequoia groves. Science 262: 885-889.

Swetnam, T.W., C.D. Allen, and J.L. Betancourt. 1999. Applied historical ecology: using the past to manage for the future. Ecological Applications 9: 1189-1206.

Tyler, C.M., and M.I. Borchert. 2003. Reproduction and growth of the chaparral geophyte, Zigadenus fremontii (Liliaceae), in relation to fire. Plant Ecology 165: 11-20.

Veblen, T.T. 1992. Regeneration dynamics. Pages 152-187 in: D.C. Glenn-Lewin, R.K. Peet, and T.T. Veblen, editors. Plant succession. Chapman and Hall, London, United Kingdom.

Villalba, R., and T.T. Veblen. 1997. Improving estimates of total tree ages based on increment core samples. Ecoscience 4: 534-542.

Vogl, R.J., W.P. Armstrong, K.L. White, and K.L. Cole. 1977. The closed-cone pines and cypress. Pages 295-358 in: M.G. Barbour and J. Major, editors. Terrestrial vegetation of California. John Wiley and Sons, New York, New York, USA.

Waldrop, T.A., H.H. Mohr, and P.H. Brose. 2006. Early dynamics of Table Mountain pine stands following stand-replacement prescribed fires of varying intensity. Pages 471-474 in: K.F. Connor, technical coordinator. Proceedings of the $13^{\text {th }}$ biennial southern silvicultural research conference. USDA Forest Service General Technical Report SRS-92, Ashville, North Carolina, USA.

Wathen, S.F. 2006. Environmental disequilibrium, fire, and erosion in response to abrupt climate change and climate teleconnections during the Holocene in the Sierra Nevada, California. Dissertation, University of California, Davis, USA.

Westerling, A.L., H.G. Hidalgo, D.R. Cayan, and T.W. Swetnam. 2006. Warming and earlier spring increase western US forest wildfire activity. Science 313: 940-943. 
Wolf, C.B. 1948. Taxonomic and distributional studies of the New World Cypresses. El Aliso 1: $1-250$.

Zedler, P.H. 1981. Life history attributes of plants and the fire cycle: a case study in chaparral dominated by Cupressus forbesii. Pages 451-458 in: H.A. Mooney and C.E. Conrad, editors. Proceedings of the symposium on the environmental consequences of fire and fuel management in Mediterranean ecosystems. USDA Forest Service General Technical Report WO-3, Washington, D.C., USA.

Zedler, P.H. 1986. Closed-cone conifers of the chaparral. Fremontia 14: 14-17.

Zedler, P.H. 1995. Fire frequency in southern California shrublands: biological effects and management options. Pages 101-112 in: J.E. Keeley and T. Scott, editors. Brushfires in California wildlands: ecology and resource management. International Association of Wildland Fire, Fairfield, Washington, USA. 